\title{
Endocrinology and auxology of sibships with non-classical congenital adrenal hyperplasia
}

Fergus J Cameron, Niall Tebbutt, Joseph Montalto, Arthur B W Yong, Margaret Zacharin, James D Best, Garry L Warne

\section{Abstract}

The symptoms, auxological characteristics, and stimulated 17-hydroxyprogesterone (17-OHP) concentrations in a group of patients with non-classical 21-hydroxylase deficiency (NCCAH) were compared with those of their siblings. Ten index cases consisting of nine females and one male patient aged 3-33 years and 16 siblings were studied. In the sibling group five subjects were slightly virilised and of these, two females were found to have NCCAH according to their stimulated 17-OHP concentrations. The remaining nine siblings, who were not virilised, all had normal stimulated 17-OHP concentrations. Among the total NCCAH group (index cases and affected siblings) eight patients had the diagnosis made within two years of the onset of symptoms. In four patients diagnosis was delayed until adulthood. In seven patients investigated, bone age was significantly increased before treatment. The mean height and body mass index $Z$ scores of the affected patients as a total group or when divided according to skeletal maturity were not significantly different from either the normal mean or from their unaffected siblings. Virilised siblings of patients with NCCAH should have stimulated 17-OHP levels measured to exclude the disease. Patients with NCCAH do not appear to be at risk of short adult stature despite increased bone age in childhood.

(Arch Dis Child 1996; 74: 406-411)

Endocrinology and

Diabetes, Royal

Children's Hospital,

Melbourne, Australia

F J Cameron

M Zacharin

G L Warne

Department of Clinical Biochemistry, Royal Children's Hospital, Melbourne, Australia

J Montalto

A B W Yong

Department of Medicine, St Vincent's Hospital, Melbourne,

Australia

N Tebbutt

J D Best

Correspondence to: Dr Garry Warne, Director, Department of

Endocrinology and Diabetes, The Royal Children's

Hospital, Flemington Road

Parkville, 3052 Melbourde,

Australia.

Accepted 22 January 1996

Keywords: congenital adrenal hyperplasia, auxological characteristics, siblings.

Non-classic P-450C21 deficiency is believed to be the most prevalent autosomal recessive disorder in humans, with a frequency of 0.01 in the general population, and an even higher frequency in Italians, Hispanics and Ashkenazi Jews. ${ }^{1}$ It accounts for $14.3 \%$ of children presenting with premature pubarche at the Royal Children's Hospital, Melbourne. ${ }^{2}$ In non-classical congenital adrenal hyperplasia (NCCAH), affected females show none of the signs of prenatal virilisation that characterise the classic form (clitoral enlargement, labial fusion, urogenital sinus) and are not salt wasting. The phenotype of late onset congenital adrenal hyperplasia (CAH) may vary over time, and it is not uncommon for individual patients to be variably classified as either late onset or cryptic. ${ }^{3}$ In the past, many cases of such mild CAH were undoubtedly misdiagnosed, particularly if there was no known family history of the condition. These persons would therefore have been exposed to excessive androgen levels over many years, and at least some would have developed acne, hirsutism, androgenic alopecia, decreased final height, clitoromegaly, menstrual irregularity, infertility, increased fetal wastage, ${ }^{4}$ and a variety of psychological problems. ${ }^{5}$ In addition, their risk of adrenal tumour would have been increased. Some, however, may have had no clinical manifestations at all. ${ }^{6}$

The discovery of the non-classical and cryptic (or asymptomatic) forms of CAH was the result of detailed screening studies on families of patients with the classic forms of $\mathrm{CAH}$. In these studies, affected relatives were identified using a combination of hormonal markers and genetic markers (HLA B14). ${ }^{78}$ The non-classical form of $\mathrm{CAH}$ has subsequently been the subject of several family studies. $^{79-14}$ These studies found both symptomatic and asymptomatic relatives with similar endocrine and genetic profiles to the propositi. This raises the possibility that phenotypically normal siblings of children with this condition may have the cryptic form of CAH. We report on the auxological and endocrine status of propositi and siblings from 10 families in which at least one member was affected by NCCAH.

\section{Patients}

INDEX PATIENTS
Our index patients were predominantly females who presented between the ages of 3 and 33 years with some or all of the following features: premature pubarche (development of pubic hair before the age of 8 years), mild clitoral enlargement (determined by measuring the clitoral index ${ }^{15}$ ), or hirsutism. All had nonambiguous, karyotype-appropriate genitalia at birth. Seven of the index patients were recruited from NCCAH patients attending the endocrine clinic at the Royal Children's Hospital, Melbourne. Three patients were seen in private practice. Features present at the time of presentation are listed in table 1 . All of the female patients presented with premature pubarche or hirsutism. In one case the patient (F.II.3.) presented after a suicide attempt prompted by long standing depression related to her hirsute appearance. One patient was an elite athlete (G.II.2.). The single male index case (J.II.4.) was noted to have symmetrically enlarged adrenal glands when a computerised tomography (CT) scan of the chest was 
Table 1 Presenting features of cases of non-classical congenital adrenal hyperplasia (NCCAH)

\begin{tabular}{|c|c|c|c|c|c|c|c|c|}
\hline Patient & $\begin{array}{l}\text { Age at } \\
\text { diagnosis } \\
\text { (years) }\end{array}$ & $\begin{array}{l}\text { Premature } \\
\text { pubarche } \\
\text { (age of } \\
\text { onset, years) }\end{array}$ & $\begin{array}{l}\text { Hirsutism } \\
\text { (age of } \\
\text { onset, } \\
\text { years) }\end{array}$ & Oligomenorrhoea & $\begin{array}{l}\text { Accelerated } \\
\text { growth } \\
\text { (age of } \\
\text { onset, years) }\end{array}$ & $\begin{array}{l}\text { Clitoromegaly } \\
\text { (age of } \\
\text { onset, years) }\end{array}$ & $\begin{array}{l}\text { Psychological } \\
\text { changes }\end{array}$ & $\begin{array}{l}\text { Dermal } \\
\text { pigmentation }\end{array}$ \\
\hline A.II.2. & 8 & 6 & 6 & N/A & - & - & - & + \\
\hline B.II.1. & 3 & 2 & - & N/A & $2-3$ & - & - & - \\
\hline C.II.1. & 6 & $\overline{5}$ & 5 & N/A & $5-6$ & - & - & - \\
\hline C.II.2.* & 2 & 2 & 2 & N/A & - & - & - & - \\
\hline D.II.1. & 7 & 7 & - & N/A & - & - & - & - \\
\hline E.II.1. & 4 & 5 & - & N/A & - & - & - & - \\
\hline F.II.3. & 21 & 4 & 14 & + & Unk & - & + & - \\
\hline G.II.2. & 15 & 3 & 14 & + & $5-10$ & $\begin{array}{c}+ \text { (age of onset } \\
\text { uncertain) }\end{array}$ & + & - \\
\hline H.II.3. & 5 & 5 & 5 & N/A & - & - & + & - \\
\hline I.II.2. & 3 & 3 & - & N/A & - & 2 & - & - \\
\hline J.II.2.` & 39 & - & 12 & + & - & - & - & - \\
\hline J.II.4. & 33 & 9 & N/A & N/A & Unk & N/A & - & - \\
\hline
\end{tabular}

*This patient is an affected sibling not an index case. N/A=not applicable; Unk=unknown.

performed to investigate a slowly resolving respiratory infection associated with pericarditis. He had reached pubarche at nine years and had had an early pubertal growth spurt. None of the index cases had a past medical history of significant illness, none had a family history suggestive of CAH, and there was no consanguinity. Urinary pregnanetriol was raised in all cases but one in whom it was measured. None of the patients had any evidence of salt wasting or neonatal virilisation.

\section{SIBLINGS}

One sibling (F.II.1.) had simple virilising CAH. Four other siblings (C.II.2., F.II.2., G.II.1., J.II.2.) had signs of hyperandrogenism. These included: premature pubarche and hirsutism at 2.8 years (C.II.2.), premature pubarche at 3 years with a subsequent diagnosis of salt losing CAH, (F.II.1.), postpubertal hirsutism (F.II.2.), obesity, oligomenorrhoea, hirsutism, and polycystic ovaries (G.II.1.), and primary amenorrhoea associated with facial hair that required shaving on a daily basis (J.II.2.).

\section{Methods}

Auxological measures were performed by endocrinologists using standard techniques ${ }^{16}$ and expressed as $\mathrm{Z}$ scores using Frisancho's standards. ${ }^{17}$ Bone age was determined by reference to Greulich and Pyle. ${ }^{18}$

An ACTH stimulation test (using Synacthen, $0.25 \mathrm{mg}$ intravenously) was performed on 14 siblings of the index cases. Blood sampling for 17-hydroxyprogesterone (17OHP) was performed at baseline and at 30 and 60 minutes after Synacthen stimulation. Two siblings from the same family had blood sampling at baseline and 30 minutes only. Serum 17-OHP was measured by radioimmunoassay.

All assays were performed by the department of clinical biochemistry at the Royal Children's Hospital in Melbourne. The radioimmunoassays used to assess serum testosterone and 17-OHP levels have been previously reported. ${ }^{19}$ Serum sodium was measured potentiometrically, using the Kodak Ektachem 700, and plasma renin activity was measured by radioimmunoassay of generated angiotensin I (CIS Sorin Biomedica) using a previously reported method. ${ }^{20}$ Urinary pregnanetriol concentrations were measured using gas chromatography/mass spectrometry.

Normal ranges for Synacthen stimulated 17OHP have been determined at our laboratory using six normal adult females with regular menses, and no hirsutism or acne. The results concur with a series of 102 persons of varying ages. $^{21}$

Statistical analyses were performed using the Minitab program. Comparisons of height and body mass index (BMI) data were made using standard $t$ tests, except for the comparisons of heights of affected adult patients with their siblings, where the Wilcoxon rank-sum test was used. $\mathrm{Z}$ scores were calculated by subtracting the mean from the raw score and dividing by the standard deviation.

\section{Results}

The raw data obtained from studies on the NCCAH cases and their siblings are shown in tables 1 to 3 . The sibships are shown in the figure. This study was in part retrospective and hence the data collection has not been entirely uniform. The results are grouped into clinical data relating to the presentation of those with NCCAH (table 1), and endocrine/auxological data of NCCAH patients (table 2) and their unaffected siblings (table 3 ).

\section{CLINICAL PRESENTATION OF SUBJECTS WITH}

NCCAH

Presenting features

Two of the virilised siblings (C.II.2., J.II.2.) were found to have NCCAH according to their stimulated 17-OHP levels and urinary steroid profile. One of these affected siblings was diagnosed at the onset of symptoms. In the other case, the diagnosis was missed, despite symptoms of virilisation for many years, and the true diagnosis was only made by screening the siblings of affected index cases. Thus our total cohort of cases with NCCAH consisted of 11 females and one male (figure). The remaining two siblings with symptoms of hyperandrogenism had polycystic ovary disease.

The unifying modes of presentation were premature pubarche or hirsutism (table 1).

Two out of nine patients had accelerated growth (defined as crossing at least one centile 

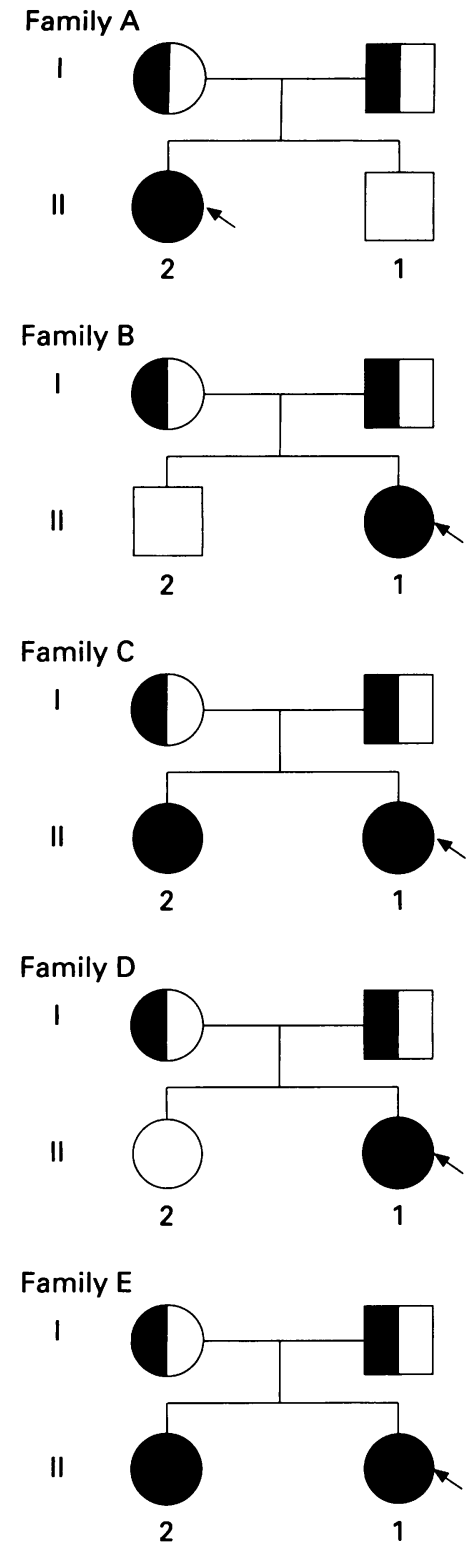

Parents are presumed heterozygotes $\rightarrow=$ index case * F.II.I. has simple virilising $\mathrm{CAH}$

Figure 1 Genograms of affected sibships.

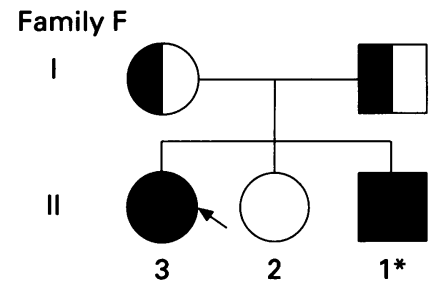

Family G

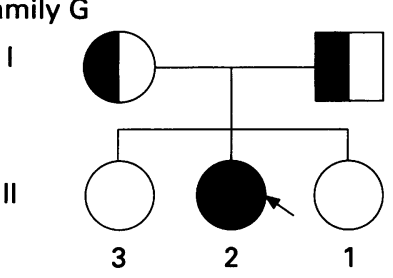

Family $\mathrm{H}$

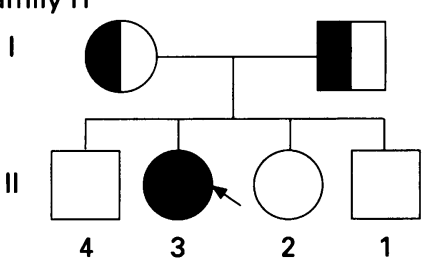

Family I

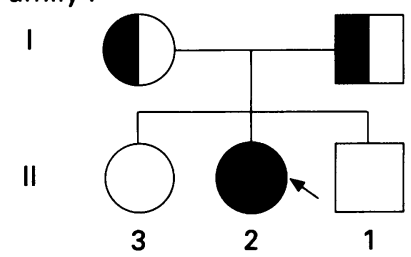

Family J

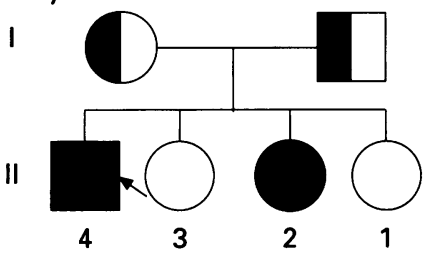

curve for stature). All patients tested $(n=7)$ had advanced bone age, the mean value being increased by 1.4 years (table 2). When the increment of bone age over chronological age is expressed as a proportion of the chronological age $[(\mathrm{BA}-\mathrm{CA}) / \mathrm{CA}]$, the mean increase in bone age is approximately one third of the chronological age (mean value $=0.34$ ).

Clitoromegaly $(4 \times 1 \mathrm{~cm}$ for G.II. 2 and $3 \times 1$ $\mathrm{cm}$ for I.II.2) was present in two of 11 female subjects. These sizes are equivalent to clitoral indices of $40 \mathrm{~mm}^{2}$ and $30 \mathrm{~mm}^{2}$, which are clearly enlarged. ${ }^{15}$

Significant psychological changes occurred in two patients and took the form in one of suicidal depression related to her hirsute appearance, and in the other patient, aggressive behaviour at school in late childhood. Of the three female patients who were postpubertal, all suffered from oligomenorrhoea or amenorrhoea.

Age at diagnosis and delay in diagnosis

Eight out of 12 patients were diagnosed between the ages of 2 and 9 years. This group accounts for all of those in whom the diagnosis was made within two years of the onset of symptoms. Significantly, four patients were diagnosed in either late adolescence or adulthood despite having had symptoms and signs for a number of years. The delay was due to parental factors in one case, and in the others it was attributable to inappropriate medical advice.

\section{Response to treatment}

Eleven out of 12 patients had been treated for their NCCAH, although in three the duration of treatment was less than six months. Treatment included a replacement glucocorticoid alone (hydrocortisone or prednisolone; $\mathrm{n}=7$ ), a replacement glucocorticoid and a mineralocorticoid (cortisone acetate and fludrocortisone; $n=2$ ), an androgen blocking agent alone (cyproterone acetate; $n=1$ ), and oestrogen and an androgen blocking agent (ethinyl oestradiol and cyproterone acetate; $n=1$ ).

On these regimens six out of eight patients had a good response with the disappearance of pubic hair. A good outcome was seen with all

Table 2 Raw data obtained at the time of presentation: cases of non-classical congenital adrenal hyperplasia

\begin{tabular}{|c|c|c|c|c|c|c|c|c|c|c|c|c|}
\hline Patient & $\begin{array}{l}\text { Age } \\
\text { (years) }\end{array}$ & Sex & $\begin{array}{l}\text { Height } \\
(\mathrm{cm})\end{array}$ & $\begin{array}{l}\text { Height } \\
Z \text { score }\end{array}$ & $\begin{array}{l}B M I \\
\left(\mathrm{~kg} / \mathrm{m}^{2}\right)\end{array}$ & $\begin{array}{l}\text { BMI } \\
Z \text { score }\end{array}$ & $\begin{array}{l}\text { Baseline } \\
\text { serum } \\
17-O H P \\
(\text { nmoll })\end{array}$ & $\begin{array}{l}\text { Maximum } \\
\text { stimulated } \\
\text { serum } \\
17-O H P \\
(\text { nmoll) } \\
\text { NR: } 2 \cdot 2-6 \cdot 9\end{array}$ & $\begin{array}{l}\text { Basal serum } \\
\text { testosterone (nmoll) } \\
\text { NR: prepubertal } \\
<0 \cdot 5 ; \text { postpubertal } \\
\text { female } 0.2-2 \cdot 5 \text {, } \\
\text { male 10-35 }\end{array}$ & $\begin{array}{l}\text { Basal serum } \\
\text { sodium } \\
\text { (mmoll) } \\
\text { NR: } 135-150\end{array}$ & $\begin{array}{l}\text { Plasma renin } \\
\text { activity } \\
(n g / m) \text { h } \\
N R: 1-4\end{array}$ & $\begin{array}{l}\text { Urinary } \\
\text { pregnanetriol, at } \\
\text { diagnosis }(\mu \text { mold }) \\
\text { NR: } 0 \cdot 5-3 \cdot 5, \\
>14 \text { years; }<0.8 \\
<14 \text { years }\end{array}$ \\
\hline $\begin{array}{l}\text { A.II.2. } \\
\text { B.II.1. } \\
\text { C.II.1. } \\
\text { C.II.2. } \\
\text { D.II.1. } \\
\text { E.II.1. } \\
\text { F.II.3. } \\
\text { G.II.2. } \\
\text { H.II.3. } \\
\text { I.II.2. } \\
\text { J.II.2. } \\
\text { I.II.4 } 4\end{array}$ & $\begin{array}{r}7 \cdot 9 \\
3 \cdot 0 \\
6.7 \\
2.8 \\
7 \cdot 3 \\
5 \cdot 2 \\
21.0 \\
15.5 \\
5.8 \\
3 \cdot 2 \\
39 \\
33\end{array}$ & $\begin{array}{l}F \\
F \\
F \\
F \\
F \\
F \\
F \\
F \\
F \\
F \\
F \\
M\end{array}$ & $\begin{array}{c}133 \cdot 4 \\
103.5 \\
116.6 \\
93.0 \\
125 \cdot 6 \\
106 \cdot 2 \\
162 \cdot 0 \\
164 \cdot 0 \\
118 \cdot 3 \\
99 \cdot 1 \\
159 \\
158\end{array}$ & $\begin{array}{l}+1.53 \\
+1.29 \\
-0.30 \\
+0.64 \\
+0.23 \\
-1.07 \\
-0.16 \\
+0.12 \\
+1.17 \\
+0.31 \\
-0.58 \\
-2.94\end{array}$ & $\begin{array}{l}15 \cdot 7 \\
15 \cdot 5 \\
15 \cdot 1 \\
14 \cdot 4 \\
16 \cdot 3 \\
14 \cdot 4 \\
25 \cdot 9 \\
31 \cdot 2 \\
21 \cdot 3 \\
15 \cdot 1 \\
43 \cdot 9 \\
23 \cdot 2\end{array}$ & $\begin{array}{c}-0.11 \\
-0.14 \\
-0.23 \\
-1.07 \\
+0.21 \\
-0.64 \\
+0.65 \\
+2.65 \\
+3.41 \\
-0.42 \\
3.2 \\
-0.60\end{array}$ & $\begin{array}{c}15 \\
135 \\
15 \\
1 \\
7 \\
200 \ddagger \\
36 \\
100 \\
2 \\
177 \\
271 \\
243\end{array}$ & $\begin{array}{r}159 \\
- \\
172 \\
36 \\
57 \\
- \\
100 \\
- \\
32 \\
- \\
1175 \\
877\end{array}$ & $\begin{array}{c}0 \cdot 4 \\
3 \cdot 2 \\
0 \cdot 5 \\
- \\
0 \cdot 5 \\
\overline{3} \cdot 4 \\
4 \cdot 4 \\
0 \cdot 3 \\
\overline{4} \\
4 \cdot 1 \\
15 \cdot 7\end{array}$ & $\begin{array}{r}140 \\
138 \\
138 \\
- \\
- \\
136 \\
- \\
- \\
\overline{-} \\
139 \\
140\end{array}$ & $\begin{array}{c}2 \cdot 0 \\
7 \cdot 8 \\
3.5 \\
- \\
\overline{14.0} \\
\overline{-} \\
\overline{-} \\
23 \cdot 8 \\
-\end{array}$ & $\begin{array}{l}5 \cdot 5 \\
2 \cdot 4 \\
5.0 \\
\text { Not done } \\
1.3 \\
22 \cdot 7 \\
14 \cdot 5 \\
13.8 \\
0.2 \\
37.5 \\
77 \cdot 3 \\
17.5\end{array}$ \\
\hline
\end{tabular}

$\star$ This patient is an affected sibling not an index case. †Patient postpubertal. $¥$ This value obtained during acute hyponatraemic dehydration. $\mathrm{BMI}=$ body mass index; $\mathrm{PRA}=$ plasma renin activity; $\mathrm{BA}-\mathrm{CA}=$ bone age minus chronological age; $\mathrm{N} / \mathrm{A}=$ not applicable. 
Table 3 Raw data: unaffected siblings

\begin{tabular}{|c|c|c|c|c|c|c|c|c|c|}
\hline Patient & $\begin{array}{l}\text { Age } \\
\text { (years) }\end{array}$ & Sex & $\begin{array}{l}\text { Height } \\
(\mathrm{cm})\end{array}$ & $\begin{array}{l}\text { Height } \\
Z \text { score }\end{array}$ & $\begin{array}{l}B M I \\
\left(\mathrm{~kg} / \mathrm{m}^{2}\right)\end{array}$ & $\begin{array}{l}\text { BMI } \\
Z \text { score }\end{array}$ & $\begin{array}{l}\text { Baseline } \\
\text { serum } \\
17-O H P \\
\text { (nmoll) }\end{array}$ & $\begin{array}{l}\text { Maximum } \\
\text { stimulated } \\
\text { serum } \\
17-O H P \\
(\text { nmol/) } \\
\text { NR: } 2 \cdot 2-6 \cdot 9\end{array}$ & $\begin{array}{l}\text { Basal } \\
\text { testosterone (nmoll) } \\
\text { NR: prepubertal } \\
<0 \cdot 5 ; \text { postpubertal } \\
\text { female } 0 \cdot 8-2 \cdot 5 \text {, } \\
\text { male } 10-35\end{array}$ \\
\hline $\begin{array}{l}\text { A.II.1. } \\
\text { B.II.2. } \\
\text { D.II.2. } \\
\text { E.II.2. } \\
\text { F.II.2. } \\
\text { G.II.1. } \\
\text { G.II.3. } \\
\text { H.II.1. } \\
\text { H.II.2. } \\
\text { H.II.4. } \\
\text { I.II.1. } \\
\text { I.II.3. } \\
\text { J.II.1. } \\
\text { J.II.3 }\end{array}$ & $\begin{array}{c}11 \cdot 2 \\
12 \cdot 3 \\
7 \cdot 7 \\
1 \cdot 8 \\
- \\
23 \cdot 3 \\
16 \cdot 9 \\
14 \cdot 3 \\
11 \cdot 7 \\
6 \cdot 8 \\
4 \cdot 9 \\
0 \cdot 2 \\
40 \\
36\end{array}$ & $\begin{array}{l}M \\
M \\
F \\
F \\
F \\
F \\
F \\
M \\
F \\
M \\
M \\
F \\
F \\
F\end{array}$ & $\begin{array}{c}144 \cdot 0 \\
152 \cdot 3 \\
132 \cdot 4 \\
82 \cdot 0 \\
\overline{170 \cdot 9} \\
169 \cdot 7 \\
165 \cdot 4 \\
144 \cdot 1 \\
126 \cdot 3 \\
111 \cdot 2 \\
55 \cdot 5 \\
161 \\
162\end{array}$ & $\begin{array}{r}-0.32 \\
+0.01 \\
+1.37 \\
+0.29 \\
- \\
+1.22 \\
+1.14 \\
-0.31 \\
-0.21 \\
+1.31 \\
+1 \cdot 22 \\
- \\
0.25 \\
-0.12\end{array}$ & $\begin{array}{l}16 \cdot 8 \\
20 \cdot 1 \\
18 \cdot 1 \\
15 \cdot 7 \\
\overline{27} \\
26 \cdot 8 \\
22 \cdot 7 \\
19 \cdot 6 \\
25 \cdot 7 \\
15 \cdot 1 \\
17 \cdot 1 \\
23 \cdot 9 \\
30 \cdot 4\end{array}$ & $\begin{array}{r}-0.45 \\
+0.34 \\
+1.16 \\
-0.67 \\
-\overline{1} \\
+1.07 \\
+1.15 \\
+0.73 \\
+0.18 \\
+5.21 \\
-0.46 \\
-0.31 \\
0.88\end{array}$ & $\begin{array}{l}1 \\
2 \\
2 \\
1 \\
1 \\
1 \\
7 \\
3 \\
1 \\
2 \\
1 \\
5 \\
1.5 \\
0.9\end{array}$ & $\begin{array}{c}6 \\
10 \\
8 \\
26 \\
8 \\
3 \\
11 \\
14 \\
5 \\
18 \\
5^{\star} \\
5^{\star} \\
20 \\
6 \cdot 7\end{array}$ & $\begin{array}{l}0.7 \\
1.3 \\
0.3 \\
- \\
\overline{0} \\
0 \cdot 7 \\
1.0 \\
4.8 \\
0.3 \\
\overline{0} \\
0 \cdot 2 \\
0 \cdot 2 \\
- \\
-\end{array}$ \\
\hline
\end{tabular}

$\mathrm{BMI}=$ body mass index. ${ }^{\star}$ Results are 30 minutes post-Synacthen.

treatment regimens except that of a brief trial of cyproterone acetate alone. The patient (D.II.1.), who remained untreated after a failed trial of hydocortisone alone, had persistence of pubic hair and experienced spontaneous normalisation of her growth velocity with normalisation of her unstimulated 17-OHP levels. Three patients were postpubertal and suffered from oligomenorrhoea (F.II.3., G.II.2., J.II.2.) which improved with glucocorticoid replacement alone in two and with glucocorticoid therapy and androgen blockade combined with oestrogen replacement in one. Fertility is unknown in these three patients. The patients with clitoromegaly required surgical reduction.

\section{ENDOCRINE EVALUATION OF INDEX CASES AND SIBLINGS \\ NCCAH cases}

All of the affected siblings and patients had either a basal or Synacthen stimulated 17OHP concentration above $30 \mathrm{nmol} / \mathrm{l}$ (with a range of 32 to $1175 \mathrm{nmol} / \mathrm{l}$ ), which is consistent with a diagnosis of NCCAH. ${ }^{22-24}$ Two affected siblings (J.II.2. and J.II.4.) had higher stimulated $17-\mathrm{OHP}$ results (877 and 1175 $\mathrm{nmol} / \mathrm{l}$ ) than are normally seen in patients with $\mathrm{NCCAH}$, but their clinical presentation was unequivocally that of late onset disease.

\section{Unaffected siblings}

Among the unaffected siblings the range of stimulated 17-OHP results was between 3 and $26 \mathrm{nmol} / 1$. Three patients (E.II.2., H.II.4., J.II.1.) had values of 26,18 , and $20 \mathrm{nmol} / \mathrm{l}$ respectively, indicating heterozygosity for the mutant allele. The genetic status of patients B.II.2., G.II.3., and H.II.1. (with values of 10 , 11 and $14 \mathrm{nmol} / \mathrm{l}$ ) is also likely to be heterozygous.

\section{AUXOLOGICAL STATUS: INDEX PATIENTS AND} SIBLINGS

Height: NCCAH and unaffected siblings

Height data were available for 12 of the affected patients, and 13 of the unaffected siblings. Mean height $\mathrm{Z}$ scores were compared between affected patients and their normal siblings. Two comparisons of height were made: (1) between those who had reached final adult height (that is, females aged 15.5 years or older, males aged 17.5 years or older) and (2) between those whose epiphyses had yet to close. The rationale for separating these groups was to determine more accurately the effects of androgen excess on growth. In the former group androgen excess may cause premature epiphyseal closure and decreased height $\mathrm{Z}$ scores, whereas in the latter group accelerated growth and increased height $Z$ scores could be expected.

The mean height $\mathrm{Z}$ scores of the affected patients were not significantly different from those of the standards $(p=0.96)$, whereas the mean height $Z$ scores of the unaffected siblings were significantly greater than the standards (mean $\mathrm{Z}$ score $=0.49, \mathrm{p}=0.04$ ). In the unaffected sibling group neither those who had reached their final adult height nor those who were still growing had mean $Z$ scores that were significantly different from the mean $(p=0 \cdot 16$ for both groups).

There was no statistically significant difference between the heights of the affected patients, prior to skeletal maturity, and their unaffected siblings $(p=0.90)$. Similarly, mature heights of index cases were not significantly different from their mature siblings $(p=0 \cdot 12)$.

\section{Body mass index: NCCAH and unaffected siblings}

BMI data were available for the same patients on whom height data were available. The mean BMI Z scores of the affected patients and their unaffected siblings were not significantly different in either childhood or adulthood $(p=0.46, p=0.47$ respectively). Furthermore neither the affected patients nor their normal siblings had BMI $Z$ scores that were significantly different from those of the standards $(p=0 \cdot 23, p=0 \cdot 13$ respectively).

\section{Discussion}

This study clearly illustrates the diverse clinical manifestations of NCCAH, with index 
patients and affected siblings presenting between the ages of 2 and 39 years. Studies of siblings of our index cohort identified three individuals with 21-hydroxylase deficiency according to endocrinological and clinical criteria. Two of these patients (C.II.2 and J.II.2) had NCCAH and one (J.II.2) had not been identified before the formal assessment of these siblings, despite having typical clinical manifestations. The third patient, who was a male (F.II.1), had previously been diagnosed as having simple virilising CAH. It is notable that two of the index cases had normal basal 17-OHP results. This underscores the importance of performing an ACTH stimulated test in order to diagnose the mild variants of $\mathrm{CAH}$ due to 21-hydroxylase deficiency.

The propositi and affected siblings in our study presented with clinical features consistent with NCCAH, over the usual age range for this disorder. There have been no previous reports of the time of delay in diagnosis and it is not clear whether or not our experience - of more than half the cases having greater than one year between the onset of symptoms and diagnosis - is a typical one. NCCAH due to 21-hydroxylase deficiency has been found to account for up to $30 \%$ of children with precocious pubarche. In a recent hospital based survey at our institution the frequency was $14.3 \% .^{2}$ Hirsutism, defined as the presence of hair on a woman in the same pattern and with the same temporal development as in men, was present in $33 \%$ of one case series of NCCAH ${ }^{11}$ and in $59 \%$ of our series. Analyses of the aetiologies of hirsutism, acne, and irregular menses indicate that NCCAH due to 21hydroxylase deficiency accounts for $1-30 \%$ of cases. ${ }^{25-27}$

While the use of ACTH stimulated 17-OHP levels to diagnose $\mathrm{CAH}$ is convenient and reliable, it has shortcomings when attempts are made to distinguish between various types of 21-hydroxylase deficiency and between those with the disease and those who are carriers for the disease. This is due in part to the compound heterozygosity of affected individuals resulting in a wide spectrum of disease. ${ }^{4}$ The largest study attempting to define stimulated 17-OHP thresholds for different types of $\mathrm{CAH}$ and carrier status came from New et al. ${ }^{28}$ In patients with NCCAH they reported values of stimulated 17-OHP as being less than 6.3 $\mathrm{nmol} / \mathrm{l}$ for normal patients, $6 \cdot 3-47 \cdot 7 \mathrm{nmol} / \mathrm{l}$ for carriers, and $64 \cdot 8-481 \cdot 5 \mathrm{nmol} / 1$ for affected patients with NCCAH. Several other papers have reported different stimulated 17-OHP results for NCCAH, with a lower limit for homozygotes of about $30 \mathrm{nmol} / 1 .{ }^{1422} 23$ There is a significant overlap of stimulated 17-OHP values between heterozygotes and normal individuals.

In recent years, the molecular pathology of this disease has been thoroughly investigated. The existence of a closely homologous, but inactive, pseudogene which is adjacent to the active 21-hydroxylase gene is thought to facilitate the process of gene conversion which accounts for the diversity of this disorder at a molecular level. Various point mutations associated with NCCAH result in partial 21hydroxylase activity and are thought to be derived from small gene conversions. These include Pro30Leu, Val281Leu, Arg339His, and Pro453Ser. ${ }^{29}$

However, characterisation of the underlying genetic abnormality has not provided the clinician with an infallible means of predicting the phenotype, as several investigators have found that the same genetic mutation can result in different CAH phenotypes. ${ }^{30} 31$ This discrepancy between genotype and phenotype is likely to arise because of other factors such as those governing gene regulation and androgen sensitivity. Thus neither gene analysis nor endocrine assessment can be used in isolation from the clinical presentation when classifying these patients.

We were unable to find any previous reports of auxological comparisons within NCCAH sibships. Apart from the height $\mathrm{Z}$ score of unaffected siblings, there were no significant differences in either height or BMI between the NCCAH patients and their unaffected siblings and the standard data. Among the unaffected siblings, neither those of mature height nor the immature subgroup appeared to be responsible for the increased mean height of the group as a whole, and this seemed to be a chance phenomenon. Thus our data suggest that the mild androgen excess seen in NCCAH does not cause a marked increase in growth velocity in childhood or result in clinically significant premature epiphyseal fusion and reduction in final adult height. This contrasts with reports of patients with classical CAH, who frequently show a marked decrease in stature compared with standard populations. ${ }^{32-34}$ In the seven patients who had an estimate of bone age performed, all had values greater than their chronological ages, the mean increase being 1.3 years (or one third of their chronological age).

Therefore the consequences of not treating these patients appear to relate largely to infertility, menstrual irregularity, cosmetic appearance, and psychological sequelae. While our group were not significantly shorter as adults, the advancement in bone age may be of concern, and larger untreated groups should be studied to assess the true incidence of premature epiphyseal fusion and short adult stature.

NCCAH due to 21-hydroxylase can be difficult to recognise clinically and its natural history can vary considerably. As is evidenced by our cohort, there is often a significant delay in diagnosis, with unnecessary patient distress even in patients with a family history of the disease. The short Synacthen test is rapid, simple, and inexpensive. It should be an integral part of any approach to investigating premature pubarche, hirsutism, or the symptoms of PCO. If non-classical 21-hydroxylase deficiency is diagnosed, then symptomatic siblings should also be routinely screened for the disease.

The authors acknowledge Dr Jennifer Batch, Dr George Werther, and Dr Bernard Clarke for providing data on two of the propositi. 
1 Speiser PW, Dupont B, Rubinstein P, et al. High frequency of non-classical steroid 21-hydroxylase deficiency. $A m \mathcal{F}$ Hum Genet 1985; 37: 650-67.

2 Montalto J, Yong ABW, Warne GL, et al. Non-classical adrenal hyperplasia in children with clinical hyperandrogenism. Proceedings of IX International hyperandroHormonal Steroids, 1994 [abstr]: 102.

3 Grumbach MM, Conte FA. Disorders of sex differentiation. In: Wilson JD, Foster DW, eds. Williams textbook of In: Wilson JD, Foster DW, eds. Williams textbook of 853-951.

4 Drucker S, New MI. Nonclassic adrenal hyperplasia due to 21-hydroxylase deficiency. Pediatr Clin North $\mathrm{Am} 1987$; 34: 1067-81.

5 Kuhnle U, Bullinger M, Schwarz HP, Knorr D. Partnership and sexuality in adult female patients with congenita adrenal hyperplasia. First results of a cross-sectional quality-of-life evaluation. $\mathcal{F}$ Steroid Biochem Mol Biol 1993; 45: $123-6$.

6 Miller WL. Genetics, diagnosis and management of 21hydroxylase deficiency. $\mathcal{F}$ Clin Endocrinol Metab 1994; 78: 241-6.

7 Holler W, Scholz S, Knorr D, Bidlingmaier F, Keller E, Albert ED. Genetic differences between the salt-wasting,
simple virilizing, and the non-classical types of congenital simple virilizing, and the non-classical types of congenital
adrenal hyperplasia. $₹$ Clin Endocrinol Metab 1985; 60: adrenal

8 Knorr D, Albert ED, Bidlingmaier F, Holler W, Scholz S. Different gene defect in the salt-wasting (SW), simple virilizing (SV), and nonclassical (NC) types of congenital adrenal hyperplasia (CAH). Ann NY Acad Sci 1985; 458: 71-5.

9 Dumic M, Brkljacic L, Mardesic D, Plavsic V, Lukenda M, Kastelan A. 'Cryptic' form of congenital adrenal hyperplasia due to 21-hydroxylase deficiency in the Yugoslav population. Acta Endocrinol 1985; 109: 386-92.

10 Kohn B, Levine LS, Pollack MS, et al. Late-onset steroid 21-hydroxylase deficiency: a variant of classical adrenal 21-hydroxylase deficiency: a variant of classical adre

11 Chrousos GP, Loriaux DL, Mann D, Cutler GB. Lateonset 21-hydroxylase deficiency mimicking idiopathic hirsutism or polycystic ovarian disease. An allelic variant of congenital virilizing adrenal hyperplasia with a milder enzymatic defect. Ann Intern Med 1982; 96: 143-8.

12 Gordon MT, Conway DI, Anderson DC, Harris R. Genetics and biochemical variability of variants of 21-hydroxylase deficiency. $\mathcal{F}$ Med Genet 1985; 22: 354-69.

13 Carel JC, Marrakchi Z, Roger M, Morel Y, Chaussain JL. Late diagnosis of 21-hydroxylase deficiencies in children after the age of three years. Ann Pediatr 1993; 40: 410-20.

14 Kuttenn F, Couillin P, Girard F, et al. Late-onset adrenal hyperplasia

15 Sane K, Pescovitz OH. The clitoral index: A determination of clitoral size in normal girls and in girls with abnormal sexual development. $\mathcal{f}$ Pediatr 1992; 120: 264-6.

16 Tanner JM. Normal growth and techniques of growth assessment. F Clin Endocrinol Metab 1986; 15: 411-51.

17 Frisancho AR. Anthropometric standards for the assessment of growth and nutritional status. Ann Arbor: The University of Michigan Press, 1993.
18 Greulich WW, Pyle SI. Radiographic atlas of skeletal development of the hand and wrist. Stanford, California: Stanford University Press, 1959.

19 Montalto J, Whorwood CB, Funder JW, et al. Plasma C19 steroid sulphate levels and indices of androgen bioavailability in female pattern androgenic alopecia. Clin Endocrinol 1990; 32: 1-12.

20 Yong ABW, Montalto J, Pitt J, Oakes S, Preston T, Buchanan C. Corticosterone methyl oxidase type II (CMO II) deficiency: biochemical approach to diagnosis. Clin Biochem 1994; 27: 491-4.

21 Lashansky G, Saenger P, Fishman $K$, et al. Normative data for adrenal steroidogenesis in a healthy pediatric population: age- and sex-related changes after adrenocorticotrophin stimulation. F Clin Endocrinol Metab 1991; 73: 674-86.

22 Dewailly D, Vantyghem-Haudiquet M-C, Sainsard C, et al. Clinical and biological phenotypes in late-onset 21hydroxylase deficiency. $\mathcal{F}$ Clin Endocrinol Metab 1986; 63: 418-23.

23 Fiet J, Gueux B, Gourmelen M, et al. Comparison of basal and adrenocorticotropin-stimulated plasma 21-deoxycortisol and 17-hydroxyprogesterone values as biological markers of late-onset adrenal hyperplasia. $\boldsymbol{f}$ Clin markers of late-onset adrenal hyp

24 Temeck JW, Pang S, Nelson C, New MI. Genetic defects in steroidogenesis in premature pubarche. $\mathcal{F}$ Clin Endocrinol Metab 1987; 64: 609-17.

25 Child DF, Bullock DE, Anderson DC. Adrenal steroidogenesis in hirsute women. Clin Endocrinol 1980; 12: 595-601.

26 Baskin HJ. Screening for late-onset congenital adrenal hyperplasia in hirsutism or amenorrhea. Arch Intern Med 1987; 147: 847-8.

27 Azziz R, Zacur HA. 21-Hydroxylase deficiency in female hyperandrogenism: screening and diagnosis. $\mathcal{f}$ Clin Endocrinol Metab 1989; 69: 577-84.

28 New MI, Lorenzen F, Lerner AJ, et al. Genotyping steroid 21-hydroxylase deficiency: hormonal reference data. 21-hydroxylase deficiency: hormonal

29 New M. Steroid 21-hydroxylase deficiency (congenital adrenal hyperplasia). Am f Med 1995; 98 (suppl 1): 3-8S.

30 Borman M, Kochhan L, Knorr D, et al. Clinical heterogeneity of 21-hydroxylase deficiency of sibs with identical 21-hydroxylase genes. Acta Endocrinol 1992; 126: 7-9.

31 Wilson RC, Mercado AB, Cheng KC, New MI. Steroid 21-hydroxylase deficiency: Genotype may not predict phenotype. F Clin Endocrinol Metab 1995; 80: 2322-9.

32 van der Kamp HJ, Slijper FME, Brandenburg H, et al. Evaluation of young women with congenital adrenal hyperplasia: a pilot study. Horm Res 1992; 37 (suppl 3): 45-9.

33 Young MC, Ribeiro J, Hughes IA. Growth and body proportions in congenital adrenal hyperplasia. Arch Dis Child $1989 ; 64: 1554-8$.

34 Jocham A, Kuhnle U, Knorr D, Schwarz HD. Final height and long-term follow-up of 108 adult patients with congenital adrenal hyperplasia [abstr]. Pediatr Res 1993; 33 (suppl 1): S81. 